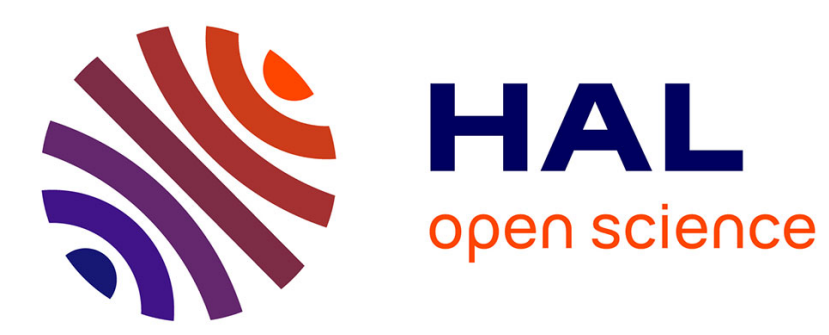

\title{
From the Firm to Economic Policy: The Problem of Coase's Cost
}

\author{
Elodie Bertrand
}

\section{To cite this version:}

Elodie Bertrand. From the Firm to Economic Policy: The Problem of Coase's Cost. History of Political Economy, 2015, 47 (3), pp.481 - 510. 10.1215/00182702-3153152 . hal-03512866

\section{HAL Id: hal-03512866 https://hal.science/hal-03512866}

Submitted on 5 Jan 2022

HAL is a multi-disciplinary open access archive for the deposit and dissemination of scientific research documents, whether they are published or not. The documents may come from teaching and research institutions in France or abroad, or from public or private research centers.
L'archive ouverte pluridisciplinaire HAL, est destinée au dépôt et à la diffusion de documents scientifiques de niveau recherche, publiés ou non, émanant des établissements d'enseignement et de recherche français ou étrangers, des laboratoires publics ou privés. 


\section{From the Firm to Economic Policy: \\ The Problem of Coase's Cost}

Elodie Bertrand ${ }^{1}$

This is the author's version of:

Elodie BERTRAND, "From the Firm to Economic Policy: The Problem of Coase's Cost", History of Political Economy (2015) 47 (3): 481-510.

https://doi.org/10.1215/00182702-3153152

One of Ronald Coase's insights was to extend the economic theory of choice to include the policy choice among institutional arrangements, which had to be analyzed with the same framework as the producer's choice. Both choices, he argued, are amenable to an opportunitycost approach. The similarity he points to, however, is somewhat limited: while some of his articles from the 1930s stressed the subjectivity of producers' decisions, his later criticisms of standard policies, as well as the method he suggests for the design of policy, are based on the idea that costs are objective and measurable. Are the subjective aspects of the production decision reconcilable with the objective aspects of the policy decision in Coase's analysis? I shall argue that the framework he adopts is objectivist or subjectivist depending on the nature of the criticism he is leveling against standard theory, and on the type of decision he is studying. Eventually he did propose a univocal analysis - an objectivist one - of the producer's decision between making and buying and the policy decision among institutional arrangements. This paper initiates a study of Coase's theory of decision. It returns to his subjectivist account of choice and contributes to solving the apparent contradiction between the subjectivist young Coase and the more mature objectivist scholar. It thereby sets out the diversity of the criticisms that Coase levels against standard theory, and shows the evolution of his strategy. Ultimately, the problem of the difference between Coase's analyses of production decisions and policy decisions is more subtle than simply being an apparent contradiction: it turns on the subjectivity of individual decisions having no consequence for his analysis of policy.

Keywords: Ronald H. Coase, comparative institutional method, opportunity cost, subjectivity.

\section{Introduction}

One of the main methodological insights offered by Ronald H. Coase was to view policy decisions as choices among different institutional arrangements. This comparative institutional method is explicit in "The Problem of Social Cost" (Coase 1960), but was already present in his previous works - for example, in "The Marginal Cost Controversy" (1946a). ${ }^{2}$ Even "The Nature of the Firm" (Coase 1937a) may be read along these lines: the producer who chooses

\footnotetext{
${ }^{1}$ CNRS (PHARE - University Paris 1 Pantheon-Sorbonne and CNRS). E-mail: Elodie.Bertrand@univ-paris1.fr. I thank Kevin D. Hoover, Steven G. Medema and two anonymous referees for their valuable comments and suggestions on previous versions of this paper. I have also benefited from remarks made by participants at several conferences (Charles Gide, ESHET and HES) and seminars (GATE L-SE and Ermes-Phare), in particular by Richard Adelstein. Errors and omissions remain mine.

${ }^{2}$ On the reception of this idea after 1960, see Medema 2014 b.
} 
between the firm and the market is also choosing between institutional arrangements. Analyzing the producer's decision in this way had, in effect, determined the framework within which policy decisions were to be analyzed.

In his 1960 article on social cost, Coase asserts that the analysis of the production decisions of firms also provides the analytical framework of policy decisions: "Economists who study problems of the firm habitually use an opportunity cost approach and compare the receipts obtained from a given combination of factors with alternative business arrangements. It would seem desirable to use a similar approach when dealing with questions of economic policy and to compare the total product yielded by alternative social arrangements" $(1960,43)$. This means that opportunity-cost reasoning explains the producer's decision and is also to be used in the comparative institutional method.

Did Coase, like the economists to whom he refers in this quotation, use a similar approach to analyze the producer's decision and the policy decision? In particular, did he apply, to the case of policy, the subjective aspects of the producer's decision that he illuminated while at the London School of Economics in the 1930s?

Coase enrolled in a commerce degree at this school in $1929 .{ }^{3}$ There, he was very much influenced by his professor Arnold Plant, who initiated him into economic reasoning and the benefits of a competitive system. Even as a teacher at the Dundee School of Economics (193234) and at the University of Liverpool (1934-35), Coase's "association with LSE never ceased" (Coase 1982, 31) and he came back to teach at LSE from 1935 until 1951 (when he left for the United States). Within Plant's research group on industrial organization - with Ronald F. Fowler, Ronald S. Edwards and George F. Thirlby - Coase contributed to the development of the notion of subjective opportunity cost (Buchanan 1969; Buchanan and Thirlby 1973) through his reflection on the notion of cost. Some of his 1930s articles testify to his subjectivist analysis of the producer's decision.

This subjectivity, however, is not present in his later criticisms of standard policies and in the method he suggests for the design of policy, which are based on the idea of costs being objective and measurable, as noted by James Buchanan $(1984,11)$. It then seems that Coase evolved from subjectivism to objectivism. To understand this evolution, it is necessary to examine whether the subjective aspects of the producer's decision, as brought to light by Coase in the 1930s, and the objective aspects of the policy decision he studied later, are reconcilable. How can we interpret Coase's assertion that it is necessary to deal with these types of decision using the same approach, given that he himself seems to operate differently? I will argue that he sometimes uses an objectivist framework and sometimes a subjectivist one, and that his preference depends on the nature of the criticism he is leveling against standard theory, and on the type of decision that he is studying. This will lead me to conclude that Coase did analyze the producer's decision between making and buying, and the policy decision among institutional arrangements, in the same objectivist way.

By examining the parallels and then the differences between Coase's analyses of production and policy decision, and by proposing a reconciliation based on the type of decision examined and the type of criticism raised, this article initiates the study of Coase's theory of

\footnotetext{
${ }^{3}$ For biographical information on Coase, see Coase 1995, Medema 1994, and Marciano 2014.
} 
decision. The essay returns to his subjectivist accounts of cost - an aspect of Coase's work that has not been widely commented upon, except by Buchanan (1969) and Aréna (1999) - and contributes to solving the apparent contradiction between the subjectivist young Coase and the objectivist mature scholar. It thereby illustrates both the diversity of the criticisms that Coase addressed to standard theory, and the evolution of his strategy.

\section{The generalization of the reasoning in terms of choice and opportunity cost}

Coase began his reflections on the notion of opportunity cost while at the London School of Economics. In the 1930s, two groups of economists were active within LSE. In the economics department, the group led by Lionel Robbins, with Abba Lerner, Nicholas Kaldor, John R. Hicks and Friedrich Hayek, was "making great strides at that time in the development of economic theory" (Coase 1970, 114). In the commerce department, Arnold Plant's research group on industrial organization aimed to apply the theoretical developments that were taking place in the first group to the management of firms. This second group, in particular Coase, Fowler, Edwards and Thirlby, was interested in the new developments on costs and pricing, and even more in the use of these analyses to understand practical economic problems. Coase recollects that "[i]n our discussions we stressed the practical aspects of these theoretical developments. We treated them seriously, but we treated them as ideas to be applied in the real world" (ibid., 115). ${ }^{4}$ They specifically studied the application of the economic notion of cost to business problems and its implications for accounting, because they were concerned with realism in the analysis of the decisions of producers. ${ }^{5}$ And their work had a particular focus on introducing the concept of opportunity cost into practical management.

Plant's group was concerned with how this economic concept had to thoroughly modify the practice of accounting so that it could actually help entrepreneurial decisions. Coase synthesized their views, writing a series of twelve short articles published in The Accountant in 1938, and titled "Business Organization and the Accountant" (Coase [1938] 1973), which were the results of this collective work (with Edwards and Fowler in particular). In this text, cost is explicitly linked to the process of choice, since Coase defines it as a lost opportunity:

[T] he notion of costs which will be used is that of 'opportunity' or 'alternative' cost. The cost of doing anything consists of the receipts which could have been obtained if that particular decision had not been taken. ... This particular concept of costs would seem to be the only one which is of use in the solution of business problems, since it concentrates attention on the alternative courses of action which are open to the businessman. (Coase [1938] 1973, 5.16) ${ }^{6}$

\footnotetext{
${ }^{4}$ See also Coase 1982, 33. On the history of Coase at LSE, see Bertrand 2015a and Bylund 2014.

${ }^{5}$ For general studies on Coase's views of the nature of economics, see Medema 1994, ch 6; Medema 1995; Medema and Zerbe 1998; Mäki 1998c and Wang 2003. Some specific issues have been raised: his realism (Mäki 1998a; 1998b; Pratten 2004; Bertrand 2015b), his views of the roles of markets and regulation (Medema and Samuels 1997; 1998; Pratten 2001; Campbell and Klaes 2005), and the tension between orthodoxy and heterodoxy (Foss 1994).

${ }^{6}$ My references to Coase [1938] 1973, as well as to Buchanan 1969 and Buchanan 1973 are to the electronic versions available at the Library of Economics and Liberty (econlib.org) and therefore contain no indication of pages, but refer to chapters and paragraphs.
} 
In Coase's view, businessmen use an opportunity-cost approach to make their decisions, but accountants do not help them in doing so properly since they have a different view of costs, defined as monetary expenditures.

Coase thus introduces here the idea that the decisions of businessmen are based on an opportunity-cost analysis. In addition, as will now be argued, his 1937a and 1946a works are to be read as extensions of the economic theory of choice to a choice among institutional arrangements - first for the producer and, second, for the agent who designs policy. Finally, it is in "The Problem of Social Cost" that Coase will draw a parallel between the policy choice of institutional arrangements and the businessman's decision using opportunity-cost analysis: this will make explicit that the policy-designer must apply the opportunity-cost reasoning to his comparative institutional approach.

\subsection{The producer's choice}

"The Nature of the Firm" (Coase 1937a), like the 1938 article, examines how the businessman really decides. This time, Coase identifies a new choice faced by the businessman, a choice that was not dealt with before in economics. As early as 1932, when he was thinking about the reasons for vertical integration, Coase wrote a letter to his fellow student Fowler, in which he formulated the question of the existence of the firm in terms of a choice of the producer: "Assume a producer of some finished product finds he needs a special part. Then, he has two alternatives. One, to produce it himself and two, to let a supplier produce it" (quoted in Coase 1988b, 15). ${ }^{7}$ Coase's insight was to bring to light a choice faced by the businessman that was not analyzed before. This idea of choice appears also in the final article: "We have to explain the basis on which, in practice, this choice between alternatives is effected" (Coase 1937a, 389). And this way of thinking is confirmed in the 1988 lectures on the Firm article: "I thought about the firm in terms of a choice of contractual arrangements" (Coase 1988b, 29). This was the first innovation of this article, the second being the identification of the costs implied by this choice.

The benefit of each alternative is the cost saved by not resorting to the other. Resorting to the firm is explained by the greater cost of the alternative: "The main reason why it is profitable to establish a firm would seem to be that there is a cost of using the price mechanism" (Coase 1937a, 390). Conversely, recourse to the market is explained by "the costs of organising" (ibid., 394), which imply "diminishing returns to management" (ibid., 395).

Coase's introduction of the notion of cost allowed him to use standard economic tools, namely Marshallian tools of substitution at the margin (ibid., 386-7), in order to induce "formal relations which are capable of being conceived exactly" (Robbins [1932] 1945, 66 quoted in Coase 1937a, 387, Robbins' emphasis). As with factors of production, at equilibrium, the marginal costs of the market and of the firm are equal, and that equality determines the size of firms (Coase 1937a, 395). This equilibrium is optimal: "In a competitive system, there is an

\footnotetext{
${ }^{7}$ Coase's thought on vertical integration was nurtured by his investigations in the United States during the period 1931-32. He found an explanation of integration by transaction costs in the summer of 1932 and wrote a draft of the article on the firm in 1934 ( $c f$. Coase 1988b).
} 
'optimum' amount of planning!” (ibid., 389, fn 3). ${ }^{8}$ The choice between firm and market is thought to be like a choice between substitutable factors of production (see ibid., p. 392). Thanks to the formal notion of cost, "the whole of the 'structure of competitive industry' becomes tractable by the ordinary technique of economic analysis" (ibid., 398). It is in this sense that Coase wrote to Fowler in October 1932 that he had "certainly succeeded in linking up organization with cost" (quoted in Coase 1988b, 4). ${ }^{9}$ This straightforward formulation, used four times in his lectures on "The Nature of the Firm" (also pp. 17, 24 and 26), translates his concern for thinking about a new subject - organization - in a way that could nevertheless involve the traditional economic analysis of choice. Cost is here thought as an obstacle whether it is real or of opportunity does not matter for understanding this choice and formalizing it.

However, the last section of Coase [1938] 1973 gives an illustration of this choice with the opportunity-cost concept. The first draft of that article dealt precisely with the choice between making and buying, but "Edwards complained bitterly that the accountants for whose benefit the articles were supposedly written would not understand what I was talking about, as the concepts and terminology I used would be completely foreign to them" (Coase 1990a, 7). Coase "therefore decided to write an introductory section in which [he] explained the character of [Coase's] approach. However, the introductory section came to occupy the whole of the twelve articles, and business problems were not discussed except as illustrations of the value of [his] approach" (ibid., 7). This led to the definition of the opportunity-cost notion. When Coase moves on to the vertical-integration decision - meant to be an illustration - he examines how an electricity-supply business owning a coal mine chooses the amount to produce itself, by comparing the (total and marginal) avoidable cost of producing to the cost of buying. ${ }^{10}$ Therefore Coase applies here opportunity-cost reasoning to the producer's choice between firm and market.

\subsection{The policy choice}

A similar extension of the application of choice analysis to the choice between institutional arrangements, this time in the policy arena, is to be found in Coase's article on "The Marginal Cost Controversy" (1946a), which criticizes the marginal-cost pricing policy for decreasingaverage-cost firms. Criticizing the automaticity of the recourse to public intervention in this case, Coase reintroduces the genuine policy choice between the price system and governmental

\footnotetext{
${ }^{8}$ See also Coase 1992, 715-6. Another formulation is this one: "This results in the institutional structure of production being that which minimizes total costs for the output produced" (Coase 1988b, 39).

9 The meaning of this expression is indeed clear: "In saying that my concept of the firm was manageable, what I had in mind was that, looking at the firm in this way, we could analyze its activities using standard economic theory. This is what I meant when I said in the letter to Fowler . . . that I had succeeded in linking up organization with cost" (Coase 1988b, 24).

${ }^{10}$ Coase will later explain that this example came precisely from his trip in the United States in 1931-32-where he was investigating integration and costs functions (Coase 1988b) - and a visit to a specific firm. Quoting a letter to Fowler written in March 1932, he said: "I added [in this letter] that, although obtaining information is difficult, 'occasionally I am well rewarded as when the other day in the case of a power plant which had integrated with some coal-mines, I was shown actual cost curves that they had constructed.' Although I don't say this in my letter to Fowler, the power company concerned was the Duquesne Power and Light Company of Pittsburgh, and some years later I adapted their figures for use in an article on the rationale of cost accounting" (ibid., 13).
} 
action. This appears when he compares these two modes of allocating resources: "No Government could distinguish in any detail between the varying tastes of individual consumers ... ; without a pricing system, a most useful guide to what consumers' preferences really are would be lacking; furthermore, although a pricing system puts additional marketing costs on to consumers and firms, these may in fact be less than the organising costs which would otherwise have to be incurred by the Government" (ibid., 172). Like the price system and the firm in "The Nature of the Firm," recourse to public intervention entails specific costs and benefits.

This way of thinking about policy in terms of institutional choice is confirmed in another of Coase's criticisms leveled against the automaticity of public intervention, this time as regards nuisances, specifically radio broadcasting interferences. ${ }^{11}$ Here again, not only does the price system have to be envisaged, but also the costs of each alternative must be taken into account:

This discussion should not be taken to imply that an administrative allocation of resources is inevitably worse than an allocation by means of the price mechanism. The operation of a market is not itself costless, and, if the costs of operating the market exceeded the costs of running the agency by a sufficiently large amount, we might be willing to acquiesce in the malallocation of resources resulting from the agency's lack of knowledge, inflexibility, and exposure to political pressure. $(\text { Coase 1959, 18) })^{12}$

"The Problem of Social Cost" (Coase 1960) generalizes and makes explicit this method for designing economic policy. ${ }^{13}$ And its discussion of economic policy can be seen as an application of the concept of opportunity cost Coase discussed 20 years before.

Coase (1960) criticizes Pigou ([1932] 1948) for comparing private cost and social cost within a given institutional arrangement, and proposing arrangements that would make them equal - for example, one in which a tax is present. Coase's argument is the following: the institutional arrangement in which private and social costs are equal is not necessarily the one in which the value of production is maximized. Since " $[\mathrm{t}]$ he economic problem in all cases of harmful effects is how to maximise the value of production" (Coase 1960, 15), one must compare the values of production yielded by different arrangements and choose the one in which it is maximized, taking into account the costs of operation of each of these arrangements. Here again, Coase enlarges the nature of the choice faced by the policy designer, as he did for

\footnotetext{
${ }^{11}$ Coase did not employ the word "externality," which existed in the late 1950s but was rarely used (see Medema 2014a). He later explained that he viewed it as implying the necessity for the government to do something (Coase 1988a, 27) and therefore preferred the expression "harmful effects." On Coase's implicit definition of externalities, see Berta and Bertrand 2014.

12 And when regulation is chosen, the choice of the type of regulation entails an opportunity-cost analysis: "A government department, in making up its mind whether or not to undertake a particular activity, should weigh against the benefits this would confer, the costs which are also involved: that is, the value of the production elsewhere which would otherwise be enjoyed" (Coase 1959, 21).

13 This article is also an extension of "The Marginal Cost Controversy" on numerous fronts, see Bertrand and Marciano 2015.
} 
the businessman. The arrangements compared in the 1960 article are the market (with initial allocation of the right to the pollutee or the polluter), the firm, direct regulation, tax, and doing nothing at all. Rather than the Pigovian comparison between different products of the same arrangement, Coase explains that it is "preferable to use the opportunity cost concept and to approach these problems by comparing the value of the product yielded by factors in alternative uses or by alternative arrangements" (ibid., 40). The comparative institutional method is thus based on the concept of opportunity cost; the agent who designs policy (it can be the judge or the economist) has to think like a producer, in terms of the allocation of his factors of production, and therefore in terms of opportunity cost. At the end of the 1930s, Coase was explaining that the businessman chooses between firm and market and uses an opportunitycost approach just like when he chooses between allocations of factors of production. In 1960, Coase explains that policy decision similarly involves a choice between institutional arrangements and opportunity-cost reasoning. As already quoted in introduction: "Economists who study problems of the firm habitually use an opportunity cost approach and compare the receipts obtained from a given combination of factors with alternative business arrangements. It would seem desirable to use a similar approach when dealing with questions of economic policy and to compare the total product yielded by alternative social arrangements" (ibid., 43).

Coase's insistence on the reciprocity of the problem of harmful effects should then be interpreted as a particular case of this reasoning: there is a choice between making A or B responsible for the nuisance, each alternative having an opportunity cost. "The Problem of Social Cost" begins with this idea, which proves its centrality in Coase's argument. He asserts that the existence of a 'victim,' as long as a policy protecting her is instituted, harms the person 'responsible' for the nuisance, i.e., imposes a cost upon him. Reiterating his prior analysis $(1959,26-7)$ of the Sturges v. Bridgman (1879) case, which concerned a doctor who could no longer practice because of the noise generated by his neighbor, a confectioner, he writes: "To avoid harming the doctor would inflict harm on the confectioner. The problem posed by this case was essentially whether it was worth while, as a result of restricting the methods of production which could be used by the confectioner, to secure more doctoring at the cost of a reduced supply of confectionery products" (1960, 2, emphasis added). The sacrifice dimension of the decision to impede the confectioner from harming the doctor is here clearly indicated, as it is in the well-known example of the rancher whose cattle destroys neighboring crops: "If it is inevitable that some cattle will stray, an increase in the supply of meat can only be obtained at the expense of a decrease in the supply of crops. The nature of the choice is clear: meat or crops. What answer should be given is, of course, not clear unless we know the value of what is obtained as well as the value of what is sacrificed to obtain it" (ibid., 2, emphasis added). Reciprocity defines an opportunity cost since it implies that the cost of an alternative be equal to the sacrifice of the alternative that is not chosen. ${ }^{14}$

\footnotetext{
${ }^{14}$ The link between cost and choice in "The Problem of Social Cost" is also reminiscent of the influence that Knight 1924 had on Coase 1960 (see Kitch 1983, 215 and Coase 1993, 250). Among other things, Knight (1924) criticized the notion of cost used by Pigou ([1932] 1948) in his treatment of external economies, and asserted that "the cost of any value is simply the value that is given up when it is chosen . . [T] he universal meaning of cost is the sacrifice of a value-alternative" (1924, 592-3).
} 
Coase's comparative institutional method is therefore to be read as a further application of his understanding of the notion of opportunity cost. ${ }^{15} \mathrm{He}$ opposes this method for designing policy to what he calls "blackboard economics," which consists in studying an ideal world (see Medema 1995). On the contrary, he asserts, policy is a matter of choice among different institutional arrangements, each of them being costly, and hence the need to compare the net values of production they yield. Since no system is optimal, there is a choice to be made among costly alternatives: "Until we realize that we are choosing between social arrangements which are all more or less failures, we are not likely to make much headway" (Coase 1964, 195).

Being interested in the applicability of economic theory, Coase detailed the implications of an economic understanding of the nature of choice and of opportunity cost. This led him to conceive the nature of the choices faced by the businessman and by the policy designer in a manner that differed from standard economics. The essential common feature between these two types of decision is that both businessmen and policy designers choose among institutional arrangements and use an opportunity-cost approach. And the fact that "The Nature of the Firm" contributes to the debate about planning (see Campbell and Klaes 2005; Mo 2012; Bylund 2014) confirms the parallel between these types of decision. This adds to the idea that there is a theoretical unity between "The Nature of the Firm" and "The Problem of Social Cost." 16 But this last article is also close to that of 1938 since it parallels the choice of policy between institutional arrangements with the businessman's choice between allocations of factors of production, which uses opportunity-cost reasoning.

The main methodological element that determines the change in approach that Coase was recommending is his realism, as can be seen as early as in his first articles. This concern with realism, with practical problems, is at the origin of his reflections on cost. Following those reflections, Coase extends economic theory to include the producer's choice between making and buying and the policy choice among different arrangements. However, besides opportunity cost, there was another specific feature of his early reflection on cost: its subjectivity. Yet this dimension disappears in his analysis of the policy decision, this being potentially an important contrast with his analysis of the producer's decision.

\section{Subjective producer vs. objective policy designer}

\subsection{The subjectivity of costs in Coase's analysis of the producer's decision}

As said above, Coase's 1938 article aimed at modifying accounting so that it could better help business decisions. In that article, the "analytical difficulties" (Coase [1938] 1973, 5.10) encountered by the assessment of costs (and revenues) and the differences with the accountant's vision of cost as expenditures (ibid., 5.17) come from two main elements that

\footnotetext{
${ }^{15}$ On Coase and the comparative institutional approach, see Medema and Samuels 1998, 163 and Medema 1996a; 1996b. In describing the consequences of Coase's criterion of maximization of the value of production, Steven Pratten makes it explicit that his reasoning will be in terms of opportunity cost: "In a situation characterised by scarce resources, any option chosen implies that other options and associated goods are forgone. In order to choose appropriately between options, it becomes necessary to compare for each not just the goods that each issues in, but the lost possibilities their pursuit entails" $(2001,619)$.

${ }^{16}$ A unity that has indeed been discussed by Coase himself (1988b, 34-5) and by, for example, Guido Calabresi (1991, 1211-15), Stewart J. Schwab (1993), Yoram Barzel and Levis A. Kochin (1992), and David Campbell and Matthias Klaes (2005).
} 
imply subjectivity of costs. The first is the presence of non-monetary factors such as the ethical preferences of the businessman (ibid., 5.11). The second is the unavoidable "uncertainty" (ibid., 5.12-13) whose effect on subjectivity, argues Coase, is increased by the fact that businessmen differ in their risk-aversion, which is "purely subjective" (ibid., 5.15). Moreover, revenues and costs will be paid in the future, and therefore have to be actualized, the subjectivity coming from the preceding elements: uncertainty and "attitude to risk-taking" (ibid., 5.14-15). ${ }^{17}$ Consequently, the decision is unpredictable by an external observer, who, in other words, cannot measure the cost (ibid., 5.15). The subjectivity of costs here flows mainly from the uncertainty and some nonmonetary determinants of the producer's choice, which cannot be neglected by any body of thought that aims at being practically useful to businessmen. ${ }^{18}$

Some consequences of this subjectivist vision of cost were well understood by Coase. First, it implies that entrepreneurs maximize their (subjective) profit: "Costs will only be covered if [the businessman] chooses, out of the various courses of action which seem open to him, that one which maximizes his profits. To cover costs and to maximize profits are essentially two ways of expressing the same phenomenon" (ibid., 5.16). ${ }^{19}$ Given its context, Coase's assertion can only refer to a subjective profit: this is the businessman's subjective profit that is maximized since he chooses his subjectively preferred option among the several he considers. Second, the opportunity-cost concept is "forward-looking": "It is useless to look back at the past, except as an object lesson" (ibid., 5.17). This means that the cost influencing the decision is the ex ante opportunity cost, estimated before the decision is made, not after. Finally, costs are calculated in reference to a specific decision and cannot, therefore, be classified - as fixed and variable, for example (ibid., 5.54-55).

This 1938 article makes explicit a subjectivist conception of cost that Coase applies in other works on the decisions of producers he published in the $1930 \mathrm{~s}$, even before $1938 .^{20}$ In his article on duopoly, Coase (1935) explains that a duopolist, realizing that his competitor reacts to a modification of his price, has then to anticipate her reactions, but the decisions "would be unpredictable - except, perhaps, by a psychologist!" (ibid., 139, fn 2). In addition, the series of papers on the cycle of the pork price, written with Fowler $(1935 ; 1937 ; 1940)$, progressively introduces subjective elements to explain the expectations of pork producers. ${ }^{21}$ Finally, it is in "Some Notes on Monopoly Price" that Coase (1937b) clarifies the subjective elements of the

\footnotetext{
${ }^{17}$ Here Coase does not seem to use the terms "uncertainty" and "risk" in Knight's (1921) sense, whom he had read in 1933 (Coase 1982, 33).

${ }^{18}$ When Coase writes on accountants' costs and the actual decision process of businessmen, he no doubt has in mind the results of observations he made during his US trip.

${ }^{19}$ Buchanan sees this statement as Coase's "most significant" contribution to the history of the construction of the subjectivist notion of cost: "Any profit opportunity that is within the realm of possibility but which is rejected becomes a cost of undertaking the preferred course of action" (Buchanan 1969, 2.27).

${ }^{20}$ See also Aréna 1999.

${ }^{21}$ Their first article insists on the uncertainty of demand (Coase and Fowler 1935, 160-2), whereas the second, demonstrating that a determinate relationship between expectations and past and present prices and costs cannot be established, introduces learning, which depends on psychological factors (Coase and Fowler 1937, 79). The third article explicitly eliminates from the calculus a specific subjective cost as too difficult to measure - "the psychological cost of change to the producer" (Coase and Fowler 1940, 281) - and argues that expected prices depend on the expected costs of production factors and an expected normal profit margin, which itself depends, among other factors, on the producer's attitude toward risk (ibid., 283-7).
} 
producer's decision process. In this article, he criticizes Joan Robinson's (1933) theory that a monopolist, in order to maximize his (objective) profit, chooses the price and output combination that equalizes his marginal (objective) cost with his marginal (objective) revenue. It is worth noting that it is Coase's concern with realism that, once again, leads him to question this still-accepted part of industrial economics: "This paper aims at making monopoly analysis more useful by introducing certain of the more important modifications which have to be made if Mrs. Robinson's theory is to be of use in increasing our understanding of the working of the actual economic system" (Coase 1937b, 17). His argument, which intends to take into account realistic elements of the monopolist's decision, is developed on a number of different levels; and I shall focus here on the arguments involving subjectivity - which are more diverse than is noted by Aréna (1999), who focuses on uncertainty.

First, the monopolist does not know that equating his marginal (objective) cost and his marginal (objective) revenue maximizes his (objective) profit. What Coase means is that this principle is true but the businessman is ignorant of it. Coase does not suggest that this businessman does not maximize his profit, but what he is maximizing is his subjective profit. He does not try to maximize his objective profit, and, even if he wanted to, he could not do so because of his ignorance of the above principle. He cannot even discover the truth of this principle by tatonnement, and this is precisely because of uncertainty: he cannot determine if the variations of profit he goes through are due to variations of price, of output, or anything else (Coase 1937b, 18). Hence he contents himself with a "reasonable" solution, which is partly subjective: "So long, therefore, as the fact that there is a divergence between the price he is charging and the monopoly 'marginal cost equals marginal revenue' price does not become too obvious, the actual price that is being charged is likely to be accepted as right or reasonable" (ibid., 19, emphasis added). ${ }^{22}$ This solution does not maximize his objective profit, but the spirit of Coase's 1938 article would imply that this maximizes his subjective profit.

Coase adds that, even if monopolists were not ignorant and were willing to equate marginal (objective) cost and marginal (objective) revenue in order to maximize (objective) profit, they would face practical barriers: they would not have "the knowledge necessary to enable them" to apply this rule (ibid., 19). On the one hand, necessary information on (objective) costs will not be practically available since "there will be considerable difficulties in calculating the cost curve for each product" (ibid., 19). On the other hand, demand curves are even more difficult to know in an uncertain environment, which brings the (subjective) producer's risk-attitude into the picture (ibid., 22). He may know only his subjective opportunity costs.

Another element of subjectivity appears when Coase uses arguments that he borrows from Hicks (1935) and that bring to the fore two nonmonetary costs faced by the monopolist. ${ }^{23}$ First, there is a "subjective cost" (Coase 1937b, 28) for the monopolist of increasing the output (of working more): the monopolist "will be prepared to sacrifice some income if he can produce less or, alternatively, . . . if he is to produce more and have an equal psychic income his money income must increase" (ibid., 29). Second, Coase (ibid., 30) paraphrases Hicks, who asserts

\footnotetext{
${ }^{22}$ This suggests that the price that maximizes objective profit is not too far from that which maximizes subjective profit.

${ }^{23}$ Hicks was a lecturer at LSE between 1928 and 1935. It was because Coase took his course on monopoly in 1935 that he became interested in this subject (Coase 1988b, 23).
} 
that "the variation in monopoly profit for some way on either side of the highest profit output may often be small . . . ; and if this is so, the subjective costs involved in securing a close adaptation to the most profitable output may well outweigh the meagre gains offered. . . The best of all monopoly profits is a quiet life" $(1935,8)$. Coase is here identifying a nonmonetary cost that is a subjective cost of the decision, i.e. the cost of searching for the exact combination of price and output that maximizes (objective) profit.

Consequently, at these different levels, Coase underlines the subjectivity of costs and of producers' decisions. The monopolist does not maximize his monetary, objective profit, as defined by Robinson; he does not know that equating his marginal objective opportunity cost with his marginal objective revenue will maximize his objective profit, and not even how to calculate his marginal objective opportunity cost. He is rather making his decision in uncertainty, the process of decision is costly, and his decisions imply nonmonetary costs; these are the elements that he takes into account when he maximizes his subjective profit. ${ }^{24}$

Sources of subjectivity are also present in Coase's most famous article from the 1930s. In "The Nature of the Firm," uncertainty - which in Coase [1938] 1973 implied the subjectivity of decisions - is an essential source of transaction costs. Coase writes, for example, that uncertainty makes it impossible to completely specify a contract: "[O]wing to the difficulty of forecasting, the longer the period of the contract is for the supply of the commodity or service, the less possible, and indeed, the less desirable it is for the person purchasing to specify what the other contracting party is expected to do" (1937a, 391). He infers that: "It seems improbable that a firm would emerge without the existence of uncertainty" (ibid., 392). Besides uncertainty, some other nonmonetary aspects of decisions are stressed. For example, Coase insists that the entrepreneur's decision is influenced by his cognitive limits. ${ }^{25} \mathrm{He}$ also mentions that workers prefer small firms because "men prefer to be the heads of small independent businesses rather than the heads of departments in a large business. . . . Owing to the individualistic spirit of the smaller entrepreneurs, they prefer to remain independent" (ibid., 395, fn 1). ${ }^{26}$ This means that, for Coase, production decisions are partly influenced by subjective preferences.

Overall, in these articles written in the 1930s, Coase sees businessmen's decisions as subjective, or at least mentions possible sources of subjectivity - mainly uncertainty and nonmonetary determinants of choice. We may ask, then: Does Coase analyze the policy decision (comparison among institutional arrangements) in the same subjectivist way as he did the businessman's decision? The answer is negative: his analysis of policy uses an objectivist framework.

\footnotetext{
24 That the producer maximizes his subjective profit but not his objective one resolves the inconsistency that appears inside the 1938 article, in which Coase also asserts: "We may . . . lay down as a general rule that it will pay to expand production so long as marginal revenue is expected to be greater than marginal cost and the avoidable costs of the total output less than the total receipts. It would be Utopian to imagine that a businessman, except by luck, could manage to attain this position of maximum profit" ([1938] 1973, 5.8-9).

${ }^{25}$ Coase explains that, "as the transactions which are organised increase, the entrepreneur . . fails to make the best use of the factors of production" (1937a, 394-5).

26 These preferences partly explain the costs of organization. Coase will explain this rising supply price a bit differently later: "people working in a large firm may find the conditions of work less attractive than in a small firm and therefore will require a higher remuneration to compensate them for this" (1988b, 32).
} 


\subsection{The objectivity of costs in Coase's analysis of the policy decision}

When Coase compares, as should the agent who designs policy, the relative efficiencies of the price system and of public intervention, his framework is close to standard objectivist microeconomics. He applies the optimality condition of equality between price and cost to the objective opportunity cost, and he mentions the subjectivity of consumer preferences but not of production costs. All these elements can be found in "The Problem of Social Cost" and make it an objectivist article.

In the 1946 article on decreasing-average-cost firms, Coase's contention that the price system without cost is efficient rests on the standard view that, at general equilibrium, prices reflect objective opportunity costs. In an optimal system of prices,

the price should be the one which equates supply and demand and it should be the same for all consumers and in all uses. This implies that the amount paid for a product should be equal to the value of the factors used in its production in another use or to another user. But the value of the factors used in the production of a product in another use or to another user is the cost of the product. We thus arrive at the familiar but important conclusion that the amount paid for a product should be equal to its cost. (Coase 1946a, 172-3) ${ }^{27}$

Coase is here restating the usual definition of objective opportunity cost as the value of the alternative product - a value that, at general equilibrium, is reflected in the price of the resources used to produce it, which allows measuring this cost by money outlays. ${ }^{28} \mathrm{He}$ falls within the "orthodox" tradition of objective opportunity cost, and even makes it explicit that the cost faced by the producer is a cost for others: cost is not only the value that these resources could have for the producer in question if they were used in another manner, but also the value that they would have for another producer or consumer. He therefore argues that the price system is efficient because, in a competitive system, and if transaction costs are nil, the price reflects the objective opportunity cost of resources.

Moreover, his references to the subjectivity of consumer preferences are also standard, and intended mainly to substantiate the impossibility of the government or an agency knowing them. The same 1946 article explains that the market reflects the preferences of consumers, which is one of its advantages relative to government (ibid., 172, see supra). By stressing that the government cannot know their preferences when consumers do not have to choose, Coase refers to the subjectivity of their preferences. The same argument is used to criticize the allocation of radio frequencies by the FCC: while the market provides a "precise monetary measure," an administrative agency cannot know "the preferences of consumers for the various goods and services in the production of which radio frequencies could be used" (Coase 1959,

\footnotetext{
27 The argument can be found again in 1990, when Coase details the conditions of competition and zero transaction costs under which it holds: "[L] eaving aside the effects of monopoly, the prices paid for resources must be equal or (slightly) greater than they would yield in another use or to another user, cost (the price of the resources) is opportunity cost, and resources will be employed in such a way as to maximize the value of production. ... [I]t assumes that the operation of the market is costless" (1990a, 10, emphasis in the original).

28 This is indeed what Thirlby $(1947,52-3)$ blames the same passage for.
} 
18). Similarly, the criticism that Coase levels against taxation of harmful effects is partly based on the difficulties of obtaining the necessary information for its computation. By mentioning these information difficulties, he is referring to the usual argument concerning the subjectivity of consumer preferences: setting up a tax based "on the fall in the value of production (in its widest sense) ... would require a detailed knowledge of individual preferences and I am unable to imagine how the data needed for such a taxation system could be assembled" (Coase 1960, 41).

When Coase mentions the uncertainty faced by the government, it is therefore more often about consumers than producers, and costs of production are assumed to be objective, such as in the standard theory of value. These references to the subjectivity of consumers, which constitute part of the marginalist theory of value, are not enough to make Coase's analysis subjectivist, in particular because it ignores the subjectivity on the production side. ${ }^{29}$ In his article on the pricing of decreasing-average-cost firms, Coase (1946a) even acts as if objective opportunity costs of production were calculable by producers and government (it is necessary to apply the multipart tariff that he suggests). ${ }^{30}$ Regarding his analysis of harmful effects, it assumes that costs are objective, measurable, and observable, including the external costs hence the existence of an independent optimum. This is precisely the charge brought against him by Buchanan, Coase's former colleague at Virginia, who complains that the examples of the "Problem of Social Cost" refer to costs and benefits that are objectively measurable and identical whoever measures them; in other words, they are independently determined: "[T]hese relationships become identical in the perception of all parties to any potential exchange of rights. Hence, the unique 'efficient' (benefit maximizing or loss minimizing) allocation of resources exists and becomes determinate conceptually to any external observer ... [d] espite [Coase's] own earlier contribution to what may be called the subjectivist theory of opportunity cost" (Buchanan 1984, 11, emphasis in the original). How does this objectivity appear in "The Problem of Social Cost"?

First, and as said above, Coase's understanding of reciprocity implies that "[ $t$ ]he nature of the choice is clear: meat or crops" (Coase 1960,2). The difference with a private choice comes from the fact that the sacrificed alternative is sacrificed by the community; in other words, what is at issue is a social choice made by a policy designer (or a judge), who compares different solutions, and not an individual choice: "The real question that has to be decided is: should A be allowed to harm B or should B be allowed to harm A? The problem is to avoid the more serious harm" (ibid., 2). The policy designer has to choose between meat or crops, the cost of meat being crops and conversely. Admittedly the opportunity-cost dimension is common to the

\footnotetext{
${ }^{29}$ As noted by a referee, in their typology of externalities, Buchanan and Stubblebine (1962, 383-4) make a similar distinction between the subjectivity of consumer preferences and the objectivity of producers' costs (see also Buchanan 1969, 5.6; on Buchanan's subjectivist analysis of externalities, see Marciano 2011; 2013). There are different degrees of subjectivity (Stringham 2010), and my point is that Coase is here adopting the same degree of subjectivity as in standard microeconomics, whereas in some of his articles in the 1930s he was implying a much higher degree by taking into account the subjectivity of costs. Buchanan $(1969,2.17)$ makes the subjectivity of costs the demarcation line between "orthodox neoclassical economics" and Austrian subjectivist economics. ${ }^{30}$ Medema $(1994,49)$ raises a similar contradiction between Coase $1937 \mathrm{~b}$, in which the monopolist does not know his demand function, and Coase 1946a, in which the government has to know it to apply a multi-part tariff.
} 
private decision and the public decision, to the choice of the businessman and that of the policy designer, but, moving from the former to the latter, Coase makes subjectivity disappear.

Second, to the social choice corresponds a social and objective cost. One of the innovations of "The Problem of Social Cost" was to consider property rights like any other factor of production (and conversely), including rights (or factors) the use of which implies external effects. Consequently, the cost of such a right, such as the cost of a factor of production, is an opportunity cost: "The cost of exercising a right (of using a factor of production) is always the loss which is suffered elsewhere in consequence of the exercise of that right" (ibid., 44, emphasis added). This opportunity cost, corresponding to the social choice that has to be decided, is a social cost in the sense that it includes external costs. ${ }^{31}$ A property right whose use implies external effects will thus, like any other factor of production, and if transaction costs are nil, have a price equal to its objective opportunity cost, this one including potential external costs. This is what Coase indicates with his examples suggesting the "Coase theorem." 32 Therein, the price of the right includes the external effect, hence reflects the social objective opportunity cost, and this explains the efficiency of the price system, if its operation costs are nil, in solving the problem of externalities. In this respect, says Coase, there exists an independent optimal allocation (ibid., 16, see Berta and Bertrand 2014, 343). This was already the case in the previous article on the FCC, in which he asserted that the aim of regulation was to obtain an optimum of pollution independent from the process by which we reach it. He wrote: "The aim of such regulation should not, of course, be to eliminate smoke pollution but to bring about the optimum amount of smoke pollution. ... The conditions which make such regulation desirable do not change the nature of the problem. And, in principle, the solution to be sought is that which would have been achieved if the institution of private property and the pricing mechanism were working well" $(1959,29)$.

To sum up, Coase indeed extended to policy the choice among institutional arrangements he had discovered for the businessman. However, as far as the subjectivity of the producer is concerned - the novelty of his thought on cost that was manifest in his articles on monopoly (1937b) and accounting ([1938] 1973) - this insight disappears in his analysis of the policy decision. Further, in his works, the costs influencing the choice among institutional arrangements are objective opportunity costs. Before examining the consequences of this oblivion of subjectivity, the next section will propose an explanation for why Coase analyzes production decisions and policy decisions differently, which will qualify this difference of analysis.

\section{Which cost for which decision?}

Coase's abandonment of subjectivity when policy is at issue is surprising for the following reason. As Buchanan $(1969,2.19-21$; 1973) explains, the consequences of subjectivity were

\footnotetext{
${ }^{31}$ It will be later defined by Coase: "Social cost represents the greatest value that factors of production would yield in an alternative use" (1988a, 158).

${ }^{32}$ As is well known, Coase did not formulate any "theorem" in his "Problem of Social Cost" and focused on the positive transaction costs world (see Coase 1988a). For an interpretation of the transformation of Coase's argument into a formalized model, see Frischmann and Marciano 2015; for a review of the debate on the “theorem," see Medema and Zerbe 2000; and for a study of its roles in Coase's works, see Bertrand 2010.
} 
not understood in the 1930s and 1940s, since economists were focused on the problems of the producer, for which it was sufficient to envisage costs simply as an obstacle, and therefore it did not matter too much whether they were objective or subjective. On the contrary, Buchanan continues, subjectivity becomes essential - as Hayek, Mises or Thirlby realized - in questioning welfare economics and its policies based on what would be called "market failures": policies that, to be applied, require that costs be objectively measured, and, to be efficient, require that agents do not take into account anything else than these monetary costs in their decisions. After what has been shown in the previous section, it now seems that Coase is doing the opposite: he touches on subjectivity regarding the producer, but his criticisms of standard policies are not based on this issue. The fact that Coase was a socialist when he was stressing subjectivity - which condemns any form of socialism - and that he abandoned both socialism and subjectivism more or less at the same time (the 1940s) strengthens the surprise. ${ }^{33}$

There are, at least, two ways of understanding this abandonment of subjectivity in Coase's analysis of policy. Coase's evolution may be understood from a chronological perspective, observing that the works stressing the subjectivity of production costs were published in the 1930s, while those relating to policy came after 1945: he then would have progressively abandoned the subjectivist dimension of his thought around the 1940s. This interpretation is supported by the fact that, when he later came back to his notion of cost as elaborated in 1938, or when he addressed Buchanan's (1969) interpretation of it, he takes care to avoid any reference to subjectivity, and even seems to doubt the uniqueness of his approach. ${ }^{34}$ I here suggest a few directions, not necessarily independent, and which would require further investigation, to explain Coase's abandonment of subjectivity around the 1940s. Coase may not at first have realized the extent to which his subjectivist approach was different from standard theory; that would explain his doubts on the specificity of the LSE tradition (see fn $34)$.

At the end of 1939, Britain declared war on Germany, and Coase was mobilized until 1946, a period during which he was mostly involved in statistical works in public agencies. When he came back to LSE, he and his colleagues had moved on to other subjects: "The war intervened in 1939, and when it ended we did not return to this work" (Coase 1990a, 6). For his part, Coase focused on the criticism of standard policies, his distrust of public intervention having been reinforced during the war while working in public agencies. ${ }^{35}$ It is possible that he put aside the subjectivist dimension of his previous analyses, which was the newest and the most related

\footnotetext{
${ }^{33}$ On Coase's progressive abandonment of socialism, see Coase 1988b; 1996.

${ }^{34}$ In his 1990 recollection of the 1938 article on accounting, Coase (1990a, 8) quotes approvingly some of the elements that Buchanan (1969) retains from him (his link between cost and choice and the refusal of any classification), but does not refer to any subjectivist element. Moreover, he does not seem to fully recognize the specificity of the LSE tradition on cost brought to light by Buchanan. Speaking of the tradition developed at LSE and in particular of his own vision, he writes: "Whether Buchanan is right in his thesis that these views on cost were not those normally held by economists elsewhere I do not know" (1990a, 9); and he also said that their study of Wicksteed and Knight gave them "such a firm hold on cost theory, leaving aside whether what emerged should be considered, as Buchanan contends, as a view special to LSE” (1982, 33). There may also be a degree of Coase's legendary humility in these statements.

35 "This war-time experience did not significantly influence my views but I could not help noticing that, with the country in mortal danger and despite the leadership of Winston Churchill, government departments often seemed more concerned to defend their own interests than those of the country" (Coase 1996, 107).
} 
to his collective work in a group that no longer existed. It is also probable that his work on statistics, the numbers having been provided by government agencies, influenced him in this sense.

Over this period, the intellectual influences on Coase progressively changed, and he turned increasingly to Smith and Marshall. ${ }^{36}$ In the 1930s he was not much influenced by Marshall, but his articles on Marshall written in the 1970s (Coase 1972a; 1975) make it obvious that Coase was at this time a great admirer, even if we do not yet know when and why this change happened. ${ }^{37}$ The use of an objective opportunity cost, equal to money outlays under some conditions, as well as the coupling of subjective consumer preferences and objective production costs, would then appear as a means to move closer to his new intellectual hero.

However, the opposition between the subjectivist dimension of the analysis of producer and the objectivist dimension of that of policy affords a different interpretation, one that adopts an analytical point of view rather than a purely chronological one.

Even in the 1930s, Coase's studies of the decisions of producers are not all subjectivist. He sometimes views the producer's decision as objective. My contention is that his preference for a focus on the objective or subjective nature of the producer's decision depends on the problem he is dealing with, and on the criticism he is levelling against standard theory.

Coase had been referring to the practical impossibility of a producer calculating his marginal objective cost (in [1938] 1973 and 1937b), but he disregards this practical problem when he comes to make other criticisms of imperfect competition theory. In his articles on duopoly (1935), multi-products monopoly (1946b), and the monopoly of a durable good (1972b), he uses the rule of the equalization of marginal (objective) cost to marginal (objective) revenue, which he had criticized using subjectivist arguments in $1937 \mathrm{~b} .{ }^{38} \mathrm{He}$ does so in order to develop different criticisms of imperfect competition theory. For example, in the article on multi-products monopoly, Coase explicitly neglects a practical problem faced by the producer - who cannot measure his marginal objective opportunity cost - in order to raise another criticism - the interrelation between the costs of and the demands for the products provided by the monopoly. He indeed does accept Robinson's assumption that the producer maximizes his (objective) profit and has the necessary knowledge (Coase 1946b, 278), but refers to his previous criticism (Coase 1937b) "[f]or a discussion of some of the modifications that must be made to the assumptions of simple monopoly theory if it is to be used to explain monopoly pricing in practice" (1946b, 278, fn 3, emphasis added). His 1937b article on simple monopoly is therefore to be understood as a more external criticism, one that is practical and realistic.

This means that Coase envisages the same type of decision (about price and output) sometimes as subjective and sometimes as objective, depending on the point he wants to make. But there is a specific type of decision made by a producer that he always analyzes as objective: the choice between making and buying. "The Nature of the Firm" describes an objective choice

\footnotetext{
${ }^{36} \mathrm{I}$ am grateful to Steven Medema for this suggestion.

${ }^{37}$ Coase wrote about Marshall's influence on Plant's group: “As a student of Plant's, I studied Industry and Trade rather than the Principles but we did not slavishly adopt Marshall's views. In fact, we thought his views on cost confused and his analysis of business practices questionable" $(1982,34)$. After the 1970s, Coase published two other articles on Marshall (Coase 1984; 1990b).

38 This 1946 b article was also written before the war (Coase 1988b, 23).
} 
between the firm and the market. As seen above, its analysis of the choice between making and buying refers to the standard analysis of cost. The "scientific meaning" of the firm's size (Coase 1937a, 393) and its optimality imply objective costs for each institutional arrangement. While some elements could have implied subjectivity in this article (uncertainty, cognitive limits, personal preferences), the trade-off between the organization costs and the transaction costs is assumed to be objective, efficient, predictable, and subject to formalization. ${ }^{39}$

The same ambiguity pervades "Business Organization and the Accountant" (Coase [1938] 1973). As explained before, this is the need to explain the concept of cost used in the analysis of the choice between making and buying that led Coase to define at great length the subjective opportunity-cost notion analyzed above. However, when Coase moves on to the illustration by the case of the electricity-supply business owning a coal mine and compares the cost of producing to the cost of buying, he admittedly envisages these costs as "avoidable costs," but they are measurable by an external observer ([1938] 1973, 5.56-60). Since Coase wants to put the emphasis on a new choice faced by the producer (and the associated costs), he no longer insists on the subjective dimension. The existence of a choice between making and buying is another kind of criticism, different from the subjectivist argument, directed at standard theory.

Similarly, Coase levels different types of criticism against the standard analysis of policy: first, public intervention may be costly and inefficient, and here Coase brings in standard elements of subjectivity to criticize certain types of regulations; second, policy should be viewed as a choice among different and costly institutional arrangements, and here he appears to neglect the difficulties raised by subjectivity.

On the one hand, then, when Coase analyzes a specific type of governmental intervention (regulation, taxation), more often than not to criticize it, he insists on the subjectivity (and therefore nonobservability) of preferences, as seen above. In other words, the regulator faces information problems and therefore cannot make the right decision. Regulators are also, in Coase's view, fallible, and since they pursue their own interest they are subject to political pressures and industry capture (see, e.g., Coase 1959, 18, or Coase 1960, 18). ${ }^{40}$ This is the first type of criticism leveled at standard policies against "market failures." It assumes, as does the theory criticized, that there is a right, optimal, decision, and that utilities are subjective (but not production costs). This objectivity assumed by Coase's criticisms of standard policies falls within an internal criticism: he wants to question the policies prescribed by welfare economics on its own objectivist basis. "The Problem of Social Cost" is indeed an internal criticism of Pigovian policies, and it was originally the first aim of this article, as made clear later by Coase:

It is my view that the approach used in that article [Coase 1960] will ultimately transform the structure of microeconomics. . . I should add that in writing this article I had no such general aim in mind. I thought that I was exposing the weaknesses of Pigou's analysis of the divergence between private and social products, an analysis generally accepted by economists, and that was all. . . The

\footnotetext{
${ }^{39}$ This is a new way of bringing to light the internal tension in "The Nature of the Firm" between "orthodoxy" and "heterodoxy," in Nicolai J. Foss's (1994) terms, or between mainstream and institutionalist elements in Medema's (1996c).

${ }^{40}$ For a comparison with the figure of the judge, who is not subject to these failures, see Bertrand 2015c.
} 
significance to me of the Coase theorem is that it undermines the Pigovian system. $(1992,717)$

The 1960 article criticized not only the Pigovian method of comparing private and social cost, but also the solutions inferred from this method: public intervention would be useless if transaction costs were nil; and when they are positive, solutions such as regulation, liability of the polluter, and taxation could, even if they could be ideally applied, create insurmountable problems (mainly other effects in the system). These criticisms are all the more relevant in that they use the same general framework as Pigou. ${ }^{41}$ In the same line, the criticism of marginalcost pricing for decreasing-average-cost firms is an internal criticism, with Coase wanting to critically examine different solutions in the same framework as the advocates of marginal-cost pricing. ${ }^{42}$ In both cases, his main criticism is that standard policy solutions are internally inconsistent, and he did not need subjectivity to establish this.

On the other hand, when Coase compares different types of institutional arrangements (including public intervention), he does so as if the agent who designs policy had all the necessary information and was aiming at maximizing the value of production. Thus, not only are the subjectivity of production costs forgotten, as before, but also the information problems and the subjectivity of the decision maker, namely the fact that she pursues personal goals and has subjective preferences. The choice among institutional arrangements is envisaged as objective by Coase because its existence in and by itself constitutes a specific type of criticism: policy decision not only has to choose among different forms of direct intervention (which type of taxation or regulation), but first has to choose among different institutional arrangements (market, firm, regulation, status quo). To convey the importance of this idea, Coase does not make it more complex by incorporating a lack of information or subjectivity.

Thus, when the decisions analyzed by Coase are specified minutely, the parallel between the production decision and the policy decision that he had made may be maintained, despite the presence of subjectivity in the former and its absence in the latter. When the producer and the policy designer choose among institutional arrangements, this choice is analyzed with the same objectivist framework in "The Nature of the Firm" and in "The Problem of Social Cost." While Coase abandoned the use of a subjectivist framework in the 1940s, his analysis of this particular type of decision does not seem to have evolved.

\footnotetext{
${ }^{41}$ For example: "[T] he proposal to solve the smoke-pollution and similar problems by the use of taxes bristles with difficulties: the problem of calculation, the difference between average and marginal damage, the interrelations between the damage suffered on different properties, etc. But it is unnecessary to examine these problems here. It is enough for my purpose to show that, even if the tax is exactly adjusted to equal the damage that would be done to neighboring properties as a result of the emission of each additional puff of smoke, the tax would not necessarily bring about optimal conditions" (Coase 1960, 42, emphasis added).

42 "Now it is, I think, extremely significant that none of the advocates of the Hotelling-Lerner solution should have examined the possibilities of multi-part pricing as a solution of the problem they are considering. They write as though the only possible method of pricing is to charge a single price per unit and that the problem they have to solve is what that price should be. It may be that their reason for not examining multi-part systems of pricing was that they were sure they had in fact found the optimum system of pricing. We must therefore compare the results of adopting the Hotelling-Lerner solution with those of using multi-part pricing" (Coase 1946a, 174).
} 


\section{Conclusion}

It was at first sight surprising that Coase analyzed policy decision as an objective choice among institutional arrangements, given that he had also said that this choice was to be analyzed in the same manner as the producers' decision, a decision that he himself viewed as subjective in some of his early works. I suggested two explanations for this abandonment of subjectivity: Coase's own evolution (for which a definitive explanation is still lacking), and the variability of his framework (objectivist or subjectivist) depending on the type of criticism he is leveling against standard microeconomics. These two interpretations are not incompatible: it is possible that Coase realized that his criticisms based on subjectivity had not been heard and so focused on other types of criticisms. And he was ultimately right: "The Problem of Social Cost" succeeded in its task. In any case, the parallel between the policy decision and the production decision in Coase's analysis can still be drawn, if we specify the type of decision on both sides: namely, the type of production decision and the type of policy decision that are similar are those consisting of choices of institutional arrangement. Like the trade-off between firm and market in "The Nature of the Firm," the policy choice among institutional arrangements is studied in terms of a choice that depends on objective costs. Coase's novelty was to introduce choice where standard microeconomics did not see one or at least did not see one analyzable in economic terms: he thus insisted here on the dimension of choice, the question of subjectivity being in his mind another part of his criticism - a part that he progressively abandoned. The parallel he brings to light between policy and production problems focuses on the notion of choice. Coase freed the choice in policy from what he considered to be the automatic policy of standard theory, as he had freed the choice of the producer from the automatic decision making determined by a production function. This dimension of choice allowed him to apply the (standard) theory of cost. Not only did Coase "link organization with cost," he also linked policy with cost.

The problem of the difference between Coase's analyses of production decisions and policy decisions is therefore more subtle than simply being an apparent contradiction; it can now be seen as rooted in the fact that the subjectivity of individual decisions has no consequence for his analysis of policy. It remains, indeed, that the subjectivity Coase brought to the fore could have modified his analysis of the comparative institutional method, and this in two senses.

First, in Coase's approach to policy design, there is no information problem, although he mentioned such problems when criticizing regulation. The practical difficulty of measuring marginal opportunity cost, emphasized in Coase 1937b, should logically imply that a government cannot measure a marginal cost of a business and much less a social cost (Pasour 1996, 249). Beyond these information problems, the subjectivity of the costs that are supposed to be measured in the process of making a policy decision is neglected: Coase assumes that the production values yielded by the arrangements and the costs of operating these arrangements are objective and measurable (see also Cordato 1992). He therefore assumes that the decision maker takes into account the costs of a decision that she will not bear - hence costs that are 
objective - and that these costs are measurable in practice. ${ }^{43}$ However, a subjectivist conception of cost would entail not only the impossibility of applying policy rules that assume the existence and measure of objective costs, but also their inefficiency. That the producer takes into account nonmonetary elements in his decision in uncertainty makes it impossible for a policy designer to perfectly determine the decisions of this producer by policies based on objective costs, be they individual or social (Buchanan 1969, ch 5).

Second, the subjectivity of the policy designer herself is forgotten. The comparison between the values of production yielded by different institutional arrangements is meant to give an objective, independent, unique solution, and the policy designer is meant to choose this solution. The subjectivity of the person who makes this choice (regulator, judge or economist) is not alluded to; whereas, in a subjectivist perspective, stress is put on the person who chooses the best alternative, as well as on her valuation process (Vaughn 1980, 705).

Two interrelated consequences of subjectivity are therefore omitted by Coase's analysis of policy design: costs are not observable, and policy decisions are subjective. Like the monopolist decision, whose explanation "in practice," Coase has argued, would have to introduce the nonobservability of its determinants, policy design "in practice" would have to include the subjectivity of costs and decisions, including those of the policy designer. Coase's criticism, nonetheless, was based on another dimension of his thought on cost elaborated in the 1930 s, that of opportunity cost, which allowed him to enlarge the nature of the choice in policy.

\section{References}

Aréna, Richard. 1999. La Décision Entrepreneuriale dans l'Analyse de R. Coase: l'Apport Possible d'un Economiste Marginaliste à l'Approche Evolutionniste. Economies et Sociétés HS 35.1:31-47.

Barzel, Yoram and Levis A. Kochin. 1992. Ronald Coase on the Nature of Social Cost as a Key to the Problem of the Firm. Scandinavian Journal of Economics 94.1:19-31.

Berta, Nathalie and Elodie Bertrand. 2014. Market Internalization of Externalities: What is Failing? Journal of the History of Economic Thought 36.3:331-57.

Bertrand, Elodie. 2010. The Three Roles of the "Coase Theorem" in Coase's Works. The European Journal of the History of Economic Thought 17.4:975-1000.

- 2015a. An Underrated Originality of "The Problem of Social Cost": The LSE Source. Mimeo. 2015b. Coase's Choice of Methodology. Mimeo.

- 2015c. "The Fugitive": The Figure of the Judge in Coase's Economics. Journal of Institutional Economics, available on CJO2014. doi:10.1017/S1744137414000460.

Bertrand, Elodie and Alain Marciano. 2015. Coase, Cost, and Divergences: From "The Marginal Cost Controversy" to "The Problem of Social Cost". Mimeo.

Buchanan, James M. 1969. Cost and Choice: An Inquiry in Economic Theory. Chicago: Markham (http://www.econlib.org/library/Buchanan/buchCv6c0.html).

\footnotetext{
${ }^{43}$ On the contrary, Buchanan argues that external costs are subjective and cannot be known: "Since the persons who bear these 'costs' - those who are externally affected - do not participate in the choice that generates the 'costs,' there is simply no means of determining, even indirectly, the value that they place on the utility loss that might be avoided" $(1969,5.4)$.
} 
1973. Introduction: LSE Cost Theory in Retrospect. In Buchanan and Thirlby (1973, Essay 1).

1984. Rights, Efficiency, and Exchange: The Irrelevance of Transactions Cost. In Ansprüche, Eigentums, und Verfügungsrechte, edited by Manfred Neumann, 9-24. Berlin: Duncker and Humblot. Repr. in Liberty, Market and the State: Political Economy in the 1980s, edited by James M. Buchanan, 1986, 92-107. New York: New York University Press.

Buchanan, James M. and Wm. Craig Stubblebine. 1962. Externality. Economica 29.116:371384.

Buchanan, James M. and George F. Thirlby (eds). 1973. LSE Essays on Cost. London: London School of Economics and Political Science

(http://www.econlib.org/library/NPDBooks/Thirlby/bcthLS.html).

Bylund, Per L. 2014. Ronald Coase's "Nature of the Firm" and the Argument for Economic Planning. Journal of the History of Economic Thought 36.3:305-29.

Calabresi, Guido. 1991. The Pointlessness of Pareto: Carrying Coase Further. The Yale Law Journal 100.5:1211-37.

Campbell, David and Matthias Klaes. 2005. The Principle of Institutional Direction: Coase's Regulatory Critique of Intervention. Cambridge Journal of Economics 29(2):263-88.

Coase, Ronald H. 1935. The Problem of Duopoly Reconsidered. The Review of Economic Studies 2.2:137-43.

1937a. The Nature of the Firm. Economica 4.16:386-405.

- 1937b. Some Notes on Monopoly Price. The Review of Economic Studies 5.1:17-31.

- [1938] 1973. Business Organization and the Accountant (a series of 12 articles). The Accountant 13.October-December:470-472, 505-507, 537-538, 559-560, 607-608, 631-632, 665-666, 705-706, 737-739, 775-777, 814-815, 834-835. Repr. in Studies in Costing, edited by David Solomons, 1952. London: Sweet and Maxwell. Repr. as shorter version, with introduction in Buchanan and Thirlby (1973, Essay 5).

_ 1946a. The Marginal Cost Controversy. Economica 13.51:169-82.

. 1946b. Monopoly Pricing with Interrelated Costs and Demands. Economica 13.52: 278-94.

1959. The Federal Communications Commission. Journal of Law and Economics 2(October): $1-40$.

- 1960. The Problem of Social Cost. Journal of Law and Economics 3(October):1-44.

- 1964. The Regulated Industries: Discussion. The American Economic Review 54.3:194-7.

1970. The Theory of Public Utility Pricing and its Application. The Bell Journal of Economics and Management Science 1.1:113-28.

- 1972a. The Appointment of Pigou as Marshall's Successor. Journal of Law and Economics 15.2:473-85.

1972b. Durability and Monopoly. Journal of Law and Economics 15.1:143-9.

- 1975. Marshall on Method. Journal of Law and Economics 18.1:25-31.

1982. Economics at LSE in the 1930's: A Personal View. Atlantic Economic Journal

10.1:31-4. 
27. 1984. Alfred Marshall's Mother and Father. History of Political Economy 16.4:519-

. 1988a. The Firm, the Market and the Law. Chicago: The University of Chicago Press. 1988b. The Nature of the Firm: Origin, Meaning, Influence. Journal of Law, Economics, and Organization 4.1:3-47.

-1990a. Accounting and the Theory of the Firm. Journal of Accounting and Economics 12.1-3:3-13.

. 1990b. Alfred Marshall's Family and Ancestry. In Alfred Marshall in Retrospect, edited by Rita M. Tullberg, 9-27. Aldershot: Edward Elgar.

. 1992. The Institutional Structure of Production. The American Economic Review 82.4:713-9.

1993. Law and Economics at Chicago. Journal of Law and Economics 36.1:239-54.

1995. Ronald H. Coase. In Lives of the Laureates. Thirteen Nobel Economists, edited by William Breit and Roger W. Spencer, $3^{\text {rd }}$ ed., 227-49. Cambridge: MIT Press.

1996. Law and Economics and A. W. Brian Simpson. The Journal of Legal Studies 25.1:103-19.

Coase, Ronald H. and Ronald F. Fowler. 1935. Bacon Production and the Pig-Cycle in Great Britain. Economica 2.6:142-67.

1937. The Pig-Cycle in Great Britain: An Explanation. Economica 4.13:55-82.

1940. The Analysis of Producers' Expectations. Economica 7.27:280-92.

Cordato, Roy. 1992. Knowledge Problems and the Problem of Social Cost. Journal of the History of Economic Thought 14.2:209-24.

Foss, Nicolai J. 1994. The Two Coasian Traditions. Review of Political Economy 6.1:37-61.

Frischmann, Brett M. and Alain Marciano. 2015. Understanding The Problem of Social Cost. Journal of Institutional Economics, available on CJO2014. doi:10.1017/S1744137414000472. 2015

Hicks, John R. 1935. Annual Survey of Economic Theory: The Theory of Monopoly. Econometrica 3.1:1-20.

Kitch, Edmund W. (ed.) 1983. The Fire of Truth: A Remembrance of Law and Economics at Chicago, 1932-1970. Journal of Law and Economics 26.1:163-234.

Knight, Frank H. 1921. Risk, Uncertainty and Profit. Boston: Houghton Mifflin.

- 1924. Some Fallacies in the Interpretation of Social Cost. The Quaterly Journal of Economics 38.4:582-606.

Mäki, Uskali. 1998a. Against Posner against Coase against Theory. Cambridge Journal of Economics 22.5:587-95.

1998b. Is Coase a Realist? Philosophy of the Social Sciences 28.1:5-31.

1998c. Coase, R. H. In The Handbook of Economic Methodology, edited by John B.

Davis, D. Wade Hands and Uskali Mäki, 64-7. Cheltenham: Edward Elgar.

Marciano, Alain. 2011. Buchanan on Externalities: An Exercise in Applied Subjectivism. Journal of Economic Behavior \& Organization 80(2):280-9.

2013. Why Market Failures Are Not a Problem: James Buchanan on Market Imperfections, Voluntary Cooperation, and Externalities. History of Political Economy 45.2:223-54. 
2014. Ronald Coase: An Obituary. History of Economic Ideas 21.2:11-27.

Medema, Steven G. 1994. Ronald H. Coase. London: Macmillan.

1995. Ronald Coase on Economics and Economic Method. History of Economics Review 24(Summer):1-22.

. 1996a. Coase, Costs, and Coordination. Journal of Economic Issues 30.2:571-8.

- 1996b. Of Pangloss, Pigouvians and Pragmatism: Ronald Coase on Social Cost Analysis. Journal of the History of Economic Thought 18.1:96-114.

- 1996c. Ronald Coase and American Institutionalism. Research in the History of Economic Thought and Methodology 14:51-92.

. 2014a. "Exceptional and Unimportant"? Externalities in Economic Analysis, 19401959. Mimeo.

2014b. Neither Misunderstood Nor Ignored: The Early Reception of Coase's Wider Challenge to the Analysis of Externalities. History of Economic Ideas 22(1):111-32.

Medema, Steven G. and Warren J. Samuels. 1997. Ronald Coase and Coasean Economics: Some Questions, Conjectures and Implications. In The Economy as a Process of Valuation, edited by Warren J. Samuels, Steven G. Medema and A. Allan Schmid, 72-128. Aldershot: Edward Elgar.

1998. Ronald Coase on Economic Policy Analysis: Framework and Implications. In Coasean Economics: Law and Economics and the New Institutional Economics, edited by Steven G. Medema, 161-83. Boston: Kluwer.

Medema, Steven G. and Richard O. Zerbe Jr. 1998. Ronald Coase, the British Tradition, and the Future of Economic Method. In Coasean Economics: Law and Economics and the New Institutional Economics, edited by Steven G. Medema, 209-38. Boston: Kluwer.

2000. The Coase Theorem. In The Encyclopedia of Law and Economics, vol. I: The History and Methodology of Law and Economics, edited by Boudewijn Bouckaert and Gerrit De Geest, 836-92. Aldershot: Edward Elgar.

Mo, Zhihong. 2012. Decentralized Planning in a Market Economy? On the Nature of Coase's Research Program. The Review of Austrian Economics 25.2:115-29.

Pasour, E. C., Jr. 1996. Pigou, Coase, Common Law, and Environmental Policy: Implications of the Calculation Debate. Public Choice 87.3/4:243-58.

Pigou, Arthur C. [1932] 1948. The Economics of Welfare, $4^{\text {th }}$ ed. London: Macmillan.

Pratten, Steven. 2001. Coase on Broadcasting, Advertising and Policy. Cambridge Journal of Economics 25.5:617-38.

. 2004. The Conflict Between Formalism and Realisticness in Modern Economics: The Case of the New Institutional Economics. In The Elgar Companion to Economics and Philosophy, edited by John B. Davis, Alain Marciano and Jochen Runde, 339-63. Cheltenham: Edward Elgar.

Robbins, Lionel R. [1932] 1945. An Essay on the Nature and Significance of Economic Science, $2^{\text {nd }}$ ed. London: Macmillan.

Robinson, Joan. 1933. The Economics of Imperfect Competition. London: Macmillan.

Schwab, Stewart J. 1993. Coase's Twin Towers: The Relation between The Nature of the Firm and the Problem of Social Cost. Journal of Corporation Law 18.2:359-70. 
Stringham, Edward P. 2010. Economic Value and Costs are Subjective. In Handbook on Contemporary Austrian Economics, edited by Peter J. Boettke, 43-66. Cheltenham: Edward Elgar.

Thirlby, George F. 1947. The Marginal Cost Controversy: A Note on Mr. Coase's Model. Economica 14.53:48-53.

Vaughn, Karen I. 1980. Does it Matter that Costs are Subjective? Southern Economic Journal 46.3:702-15.

Wang, Ning. 2003. Coase on the Nature of Economics. Cambridge Journal of Economics 27.6:807-29. 